Original Research Paper

\title{
Application of Project Based Learning Insect Characteristics Around Lake Tondano in Entomology Course
}

\author{
Ferny Margo Tumbel ${ }^{1}$, Mokosuli Yermia Semuel ${ }^{2 *}$, Meike Paat $^{3}$ \\ ${ }^{1}$ Program Studi Pendidikan Biologi, Fakultas Matematika dan Ilmu Pengetahuan Alam, Universitas \\ Negeri Manado, Indonesia \\ ${ }^{2}$ Program Studi Biologi, Fakultas Matematika dan Ilmu Pengetahuan Alam, Universitas Negeri Manado, \\ Indonesia \\ ${ }^{3}$ Program Studi Pendidikan IPA, Fakultas Matematika dan Ilmu Pengetahuan Alam, Universitas Negeri \\ Manado, Indonesia
}

\author{
Article History \\ Received : November $03^{\text {th }}, 2021$ \\ Revised : December $20^{\text {th }}, 2021$ \\ Accepted : December 29 ${ }^{\text {th }}, 2021$ \\ Published : January 05 ${ }^{\text {th }}, 2022$ \\ *Corresponding Author: \\ Mokosuli Yermia Semuel \\ Program Studi Biologi, Fakultas \\ Matematika dan Ilmu \\ Pengetahuan Alam, Universitas \\ Negeri Manado, Manado, \\ Indonesia; \\ Email: \\ yermiamokosuli@unima.ac.id
}

\begin{abstract}
The online learning policy was implemented during the COVID-19 pandemic in various countries around the world. Problems arise in learning biology that requires laboratory experiment activities. This research provides an innovation in entomology learning with a project-based learning method using insect biodiversity in the local ecosystem, namely Lake Tondano. This study aims to determine the ability of science process skills and student responses using the projectbased learning method. Project-based learning is one of the methods established for the independent learning process to learn the independent curriculum. The research was conducted with an exploratory, descriptive research method. Science process skills and student project products are measured using a rubric. Student learning outcomes are measured using quiz questions with the google form application.Meanwhile, student responses were measured using a questionnaire. The study results showed that the science process skills of students who were taught using the Project-based learning method were in the good and very good categories. The resulting project output is a practical guide based on the assessment rubric which is in good and very good grades. Student responses regarding the application of Project based learning in entomology courses are in the agree and strongly agree categories. Student learning outcomes showed an average in the good and very good categories. The application of projectbased learning can stimulate the ability of science processes and student learning outcomes in entomology courses. Project-based learning is very appropriate to be applied to fields of science that require a lot of experimental activities. Because it is carried out in small research groups, the project-based learning method is appropriate for learning during the COVID-19 pandemic.
\end{abstract}

Keywords: Project-based learning, entomology, Lake Tondano, science process skills

\section{Pendahuluan}

Pandemi COVID 19 telah merubah tatanan pembelajaran di berbagai negara (Yustina et.al. 2020; Karakaya et al., 2020). Pembelajaran secara langsung digantikan dengan pembelajaran secara tidak langsung atau pembelajaran dalam jaringan (daring). Berdasarkan status penyebaran
COVID 19, beberapa daerah dimungkinkan melaksanakan pembelajaran hybrid yaitu mengabungkan daring dan luring. Pembelajaran secara daring mempengaruhi minat belajar, keterampilan dasar sains dan penguasan skill laboratorium mahasiswa. Kampus yang ditutup, praktikum tidak jalan, mahasiswa yang kembali ke rumah dan belajar dari rumah mempengaruhi 
capaian pembelajaran mata kuliah yang ditargetkan. Capaian pembelajaran mata kuliah khususnya aspek keterampilan laboratorium sulit dicapai melalui pembelajaran daring (Simanjuntak dan Wahyanti, 2021). Sangat dibutuhkan inovasi pembelajaran untuk dapat mengakomodir aspek praktikum. Disamping itu, oleh karena mahasiswa Kembali ke kampung halaman, maka diperlukan inovasi pembelajaran yang memanfaatkan potensi biodiversitas lokal (Sumampouw et.al. 2017; Semuel et.al. 2021).

Salah satu alternatif pemecahan masalah tersebut dengan melibatkan mahasiswa dalam pembelajaran basis projek. Pembelajaran berbasis proyek adalah pendekatan konstruktivis, diorganisir di sekitar proyek yang dirancang untuk merangsang pemecahan masalah, pemikiran kritis, dan otonomi pelajar menggunakan masalah yang realistis (Chen, 2019; Virtue and Hinnant-Crawford, 2019). Walaupun demikian, istilah pembelajaran berbasis proyek telah digunakan secara luas untuk mencakup banyak praktik pedagogis yang berbeda (Tretten dan Zachariou, 1997). Pembelajaran berbasis project merupakan salah satu metode pembelajaran di perguruan tinggi yang dituangkan dalam keputusan Menteri Pendidikan nomor 21 tahun 2021 (Trane et al., 2021; Affamdo et al., 2021; Sarwi et al., 2021; Torrecilla, 2021). Metode pembelajaran project diyakini mampu menurunkan kompetitif skills mahasiswa yang dibutuhkan di abad 21 ini. Pembelajaran kelompok berbasis proyek dan pembelajaran menggunakan metode pemecahan kasus merupakan dua metode pembelajaran yang berkontribusi pada indicator kinerja perguruan tinggi (Kusumawardini dan Tim KPT Dikti, 2021). Pembelajaran berbasis project dan kasus diyakini dapat membangun kemampuan kompetitif

Entomologi merupakan salah satu mata kuliah wajib dalam kurikulum Program Studi Biologi maupun Pendidikan Biologi. Entomologi mengkaji karateristik serangga. Serangga sampai saat ini memiliki anggota $2 / 3$ dari totalitas species hewan yang diketahui dibumi. Diversitas species serangga yang sangat besar, siklus hidup yang pendek, keragaman morfologi, anatomi, fisiologi dan habitat menjadikan serangga sebagai objek pembelajaran yang potensial untuk mempelajari biologi secara komprehensif (Semuel et.al. 2021; Mokosuli, 2013; Wurarah and Mokosuli, 2019). Penelitian ini bertujuan untuk mengaplikasikan pembelajaran metode project menggunakan serangga air di sekitar di danau Tondano. Danau Tondano merupakan danau terbesar di Sulawesi Utara dan menjadi laboratorium alam bagi Jurusan Biologi Universitas Negeri Manado karena lokasinya hanya berjarak $1 \mathrm{~km}$ dari Kampus Unima.

\section{Bahan dan Metode}

Penelitian ini menerapkan metode deskriptif eksploratif yang dilaksanakan di program studi biologi Fakultas Matematika dan Ilmu Pengetahuan Alam, Universitas Negeri Manado pada bulan Februari sampai dengan Juli 2021. Subjek penelitian adalah mahasiswa semester 4 prodi Biologi FMIPA Unima tahun akademik 2020/ 2021 yang mengambil Mata Kuliah Entomologi yang berjumlah 40 orang. Data berupa Keterampilan Proses Sains (KPS) dasar mahasiswa diperoleh dari penilaian kinerja (performance assessment) (Lepiyanto, 2017; Mardhotillah et al., 2020). Pada setiap topik praktikum mandiri dan terbatas sesuai protocol COVID 19 yaitu: (1) Teknik Mikroskopi hewan; (2) bentuk dan struktur tubuh eksternal serangga; (3) bentuk dan stryktur tubuh internal serangga 4). Biokimia dan Fisiologi seranga 5) Ekologi Serangga ; (6) Peran serangga air di danau. Ketrampilan Proses Sains yang diukur berkaitan dengan kegiatan project yang dilakukan berjumlah 12 (Wurarah and Mokosuli, 2019) (Tabel 1).

Tabel 1. Keterampilan dasar Sains yang diukur

\begin{tabular}{ll}
\hline No & \multicolumn{1}{c}{ Keterampilan Dasar Sains } \\
\hline 1 & Keterampilan pengambilan sampel didanau Tondano \\
2 & Keterampilan preparasi sampel dilapangan \\
3 & Kemampuan menentukan jenis mikroskop yang digunakan \\
4 & Keterampilan preparasi sampel untuk analisis morfologi dan anatomi serangga menggunakan \\
& mikroskop \\
\hline
\end{tabular}




\begin{tabular}{ll}
\hline 5 & Kemampuan menggunakan stereomikroskop untuk pengamatan serangga \\
6 & Kemampuan menginterpretasi hasil pengamatan serangga menggunakan stereomikroskop digital \\
7 & Keterampilan melakukan pembedahan serangga \\
8 & Keterampilan menganalisis pigmen mata pada serangga \\
9 & Kemampuan menginterpretasikan hasil pengamatan dengan bantuan statistika \\
10 & Kemampuan literasi digital jurnal \\
11 & Kemampuan mengkomunikasikan hasil proyek (laporan, buku praktikum dan portofolio) \\
12 & Kemampuan menganalisis dan menyimpulkan hasil capaian \\
\hline
\end{tabular}

Pengukuran keterampilan proses sains menggunakan model rubrik holistic yaitu digunakan memberikan penilaian terhadap keseluruhan atau holistic terhadap mutu kinerja mahasiswa (Hayashi, 2011). Kategori pengukuran ditunjukkan pada tabel 2 .

Tabel 2. Kategori Pengukuran KPS

\begin{tabular}{lll}
\hline No & Skor & Kategori \\
\hline 1 & $80-100$ & Sangat baik \\
2 & $65-79$ & Baik \\
3 & $55-64$ & Cukup \\
4 & $45-54$ & Kurang \\
5 & $\leq 44$ & Sangat \\
& & kurang/gagal \\
\hline
\end{tabular}

Hasil belajar mahasiswa diukur menggunakan soal kuis pada adengan aplikasi google form. Sedangkan respons mahasiswa diukur menggunakan kuisioner menggunakan aplikasi google form. Kuisioner respons mahasiswa terhadap metode pembelajaran yang diaplikasikan dilakukan setelah nilai diunggah pada system informasi akademik Unima, sehingga diharapkan tidak mempengaruhi objektifitas mahasiswa dalam menjawab kuisioner.

\section{Hasil dan Pembahasan}

Berdasarkan rubrik pengukuran 12 keterampilan proses sains, diperoleh 7 aspek keterampilan proses sains berada pada kategori sangat baik sedangkan 6 aspek keterampilan proses sains berada pada kategori baik. Keterampilan pengambilan sampel di danau Tondano menjadi aspek KPS yang mendapatkan rata rata capaian skor tertinggi disamping keterampilan melakukan pembedahan serangga (Tabel 3).

Tabel 3. Analisis keterampilan Proses Sains

\begin{tabular}{|c|c|c|c|}
\hline No & Aspek & $\begin{array}{l}\text { Rata-rata skor } \\
\text { aspek KPS }\end{array}$ & Kategori \\
\hline 1 & Keterampilan pengambilan sampel didanau Tondano & 83 & Sangat baik \\
\hline 2 & Keterampilan preparasi sampel dilapangan & 80 & Sangat Baik \\
\hline 3 & Kemampuan menentukan jenis mikroskop yang digunakan & 78 & Baik \\
\hline 4 & $\begin{array}{l}\text { Keterampilan preparasi sampel untuk analisis morfologi dan } \\
\text { anatomi serangga menggunakan mikroskop }\end{array}$ & 78 & Baik \\
\hline 5 & $\begin{array}{l}\text { Kemampuan menggunakan } \\
\text { pengamatan serangga }\end{array}$ & 78 & Baik \\
\hline 6 & $\begin{array}{l}\text { Kemampuan menginterpretasi hasil pengamatan serangga } \\
\text { menggunakan stereomikroskop digital }\end{array}$ & 80 & Sangat Baik \\
\hline 7 & Keterampilan melakukan pembedahan serangga & 82 & Sangat Baik \\
\hline 8 & Keterampilan menganalisis pigmen mata pada serangga & 80 & Sangat Baik \\
\hline 9 & $\begin{array}{l}\text { Kemampuan menginterpretasikan hasil pengamatan dengan } \\
\text { bantuan statistika }\end{array}$ & 78 & Baik \\
\hline 10 & Kemampuan literasi digital jurnal & 78 & Baik \\
\hline 11 & $\begin{array}{l}\text { Kemampuan mengkomunikasikan hasil proyek (laporan, } \\
\text { buku praktikum dan portofolio) }\end{array}$ & 81 & Sangat Baik \\
\hline 12 & Kemampuan menganalisis dan menyimpulkan hasil capaian & 80 & Sangat Baik \\
\hline
\end{tabular}




\section{a. Evaluasi dalam bentuk Kuis}

Dalam rangka mengevaluasi pemahaman mahasiswa, maka selama penerapan $\mathrm{PjBl}$ dalam satu semester diberikan 4 kali kuis sesuai tahapan kegiatan project yang diberikan. Soal kuis dalam bentuk pilihan ganda menggunakan aplikasi google form. Soal yang diberikan menggunakan $70 \%$ dalam bentuk interpretasi gambar. Jumlah soal yang diberikan pada tiap kuis adalah 20 butir soal. Berdasarkan nilai kuis yang diberikan, hanya pada kuis keempat yaitu materi biokimia dan fisiologi serangga mahasiswa mendapatkan rata rata nilai klasikal 78,25 atau termasuk kategori nilai B. Sedangkan pada tiga kuis yang lain yaitu materi Teknik mikroskop, stuktur tubuh serangga dan ekologi serangga; diperoleh rata rata nilai diatas 80 atau masuk kategori nilai $\mathrm{A}$ (Tabel 4).

Tabel 4. Nilai rata Rata Kuis

\begin{tabular}{llll}
\hline No & \multicolumn{1}{c}{ Materi } & Nilai Rata-rata & $\begin{array}{c}\text { Kategori } \\
\text { Nilai }\end{array}$ \\
\hline $\mathbf{1}$ & Teknik Mikroskopi hewan; bentuk dan struktur tubuh eksternal & 81,30 & A \\
& serangga; & 85,70 & A \\
$\mathbf{2}$ & Bentuk dan struktur tubuh internal serangga & 78,25 & B \\
$\mathbf{3}$ & Biokimia dan Fisiologi seranga & 85,30 & A \\
$\mathbf{4}$ & Ekologi serangga ; peran serangga air di danau & \\
\hline
\end{tabular}

\section{b. Pengukuran Produk Pembelajaran Berbasis Project}

Hasil pembelajaran berbasis project adalah buku praktikum yang dibuat oleh masing masing kelompok berdasarkan pengalaman eksperimen tiap topik yang dilakukan selama kegiatan pembelajaran. Buku Praktikum yang dihasilkan dinilai menggunakan rubrik. Hasil penelitian menunjukkan dari lima kelompok project, dua kelompok mendapatkan grade capaian sangat baik sedangkan tiga kelompok mendapatkan grade capaian baik (Tabel 5). Pembelajaran entomologi berbasis project dapat meningkatkan motivasi dan kreativitas mahasiswa biologi. Kegiatan eksperimen lapangan dan laboratorium mampu menumbuhkan kemandirian, pemecahan masalah dan kesimpulan dengan retensi yang kuat dari topik atau materi yang dipelajari (Barry et al., 2020; Lamarre, et al., 2020). Lebih lanjut pendekatan project based learning, pendekatan project meningkatkan kemandirian dan problem solving mahasiswa. Pada mata kuliah entomologi, melalui project karakterisasi serangga di sekitar danau Tondano mampu meningkatkan sikap konervasi, kemampuan literasi dan ide pemecahan masalah biodiversitas danau.
Tabel 5. Penilaian Produk Akhir Project

\begin{tabular}{llll}
\hline No & Kelompok & $\begin{array}{l}\text { Skor } \\
\text { Nilai }\end{array}$ & Grade Capaian \\
\hline 1 & I & 70 & Baik \\
2 & II & 83 & Sangat Baik \\
3 & III & 75 & Baik \\
4 & IV & 73 & Baik \\
5 & V & 87 & Sangat Baik \\
\hline
\end{tabular}

\section{Survei Kepuasan Mahasiswa}

Setelah penilaian mata kuliah di system informasi akademik Unima, diberikan survei kepada mahasiswa tentang pelaksanaan pembelajaran metode project based learning pada mata kuliah entomologi. Hasil survei menunjukkan bahwa 63,64\% mahasiswa sangat setuju dengan pernyataan pembelajaran menarik dan menyenangkan, 90,91\% mahasiswa sangat setuju pernyataan merasa puas dengan produk pjbl dalam bentuk panduan praktikum yang dihasilkan, 86,36\% mehasiswa menjawab sangat setuju mendapatkan pengalaman belajar baru. Pada pertanyaan kemudahan akses laboratorium hanya $9,09 \%$ mahasiswa menjawab sangat setuju dan 9,09\% mahasiswa menjawab tidak setuju. Objektifitas penilaian oleh dosen, 77,27 \% mahasiswa menjawab sangat setuju (Tabel 6). 
Tabel 6. Persentasi Respons Mahasiswa Terhadap pertanyaan evaluasi pembelajaran metode Project Based Learning Pada Mata Kuliah Entomologi

\begin{tabular}{|c|c|c|c|c|c|}
\hline No & Pertanyaan & $\begin{array}{c}\text { tidak } \\
\text { setuju }\end{array}$ & $\begin{array}{c}\text { biasa } \\
\text { saja }\end{array}$ & setuju & $\begin{array}{l}\text { sangat } \\
\text { setuju }\end{array}$ \\
\hline 1 & Pembelajaran menarik dan menyenangkan & 0.00 & 4.55 & 31.82 & 63.64 \\
\hline 2 & Dosen menjadi fasilitator perkuliahan dengan baik & 0.00 & 0.00 & 36.36 & 63.64 \\
\hline 3 & Panduan PjBl mudah dimengerti dan dapat dipelajari kapanpun & 0.00 & 0.00 & 40.91 & 59.09 \\
\hline 4 & Dosen memberikan layanan konsultasi diluar jam kuliah & 0.00 & 0.00 & 77.27 & 22.73 \\
\hline 5 & Objek studi serangga danau Tondano tepat untuk PjBl & 0.00 & 0.00 & 22.73 & 77.27 \\
\hline 6 & Mahasiswa mendapatkan pengalaman belajar baru & 0.00 & 0.00 & 13.64 & 86.36 \\
\hline 7 & Mahasiswa puas dengan produk $\mathrm{PjBl}$ yang dihasilkan & 0.00 & 0.00 & 9.09 & 90.91 \\
\hline 8 & Dosen menilai secara objektif & 0.00 & 0.00 & 22.73 & 77.27 \\
\hline 9 & Rubrik penilaian dikomunikasikan sejak awal perkuliahan & 0.00 & 0.00 & 0.00 & 100.00 \\
\hline 10 & Laboratorium untuk studi kelompok mudah di akses & 9.09 & 13.64 & 68.18 & 9.09 \\
\hline 11 & Teknisi laboratorium membantu pembelajaran & 0.00 & 22.73 & 54.55 & 22.73 \\
\hline 12 & Apakah metode perlu diaplikasikan pada MK lainnya & 0.00 & 0.00 & 22.73 & 77.27 \\
\hline
\end{tabular}

Pembelajaran problem based learning dapat menstimulasi kemampuan proses sains pada mahasiswa yang mempelajari mata kuliah entomologi. Berdasarkan rubrik penilaian KPS, menunjukan dari 12 paramter pengukuran KPS, 7 parameter pengukuran berada pada grade sangat baik atau mendapatkan skor 80-100. Sedangkan 5 parameter KPS yang diukur mendapatkan grade baik atau mendapatkan skor pada sebaran 70-79. Hal ini menunjukkan bahwa PjBl menggunakan objek studi serangga di danau Tondano mampu mendeskripsikan KPS mahasiswa. Lebih lanjut, dari empat evaluasi dalam bentuk kuis untuk mengukur tingkat pemahaman mahasiswa pada sub materi yang diberikan, hanya pada materi biokimia dan fisiologi serangga mahasiswa mendapatkan nilai rata rata kategori B sedangkan tiga materi yang lain yaitu Teknik mikroskop, struktur tubuh serangga dan ekologi serangga mendapatkan rata rata nilai kategori A. Hal ini menunjukkan pelaksanaan $\mathrm{PjBl}$ memberikan kontribusi yang baik pada pengetahuan mahasiswa tentang konsep konsep utama dalam entomologi. Evaluasi capaian produk $\mathrm{PjBl}$ dilakukan menggunakan rubrik menunjukkan produk yang dihasilkan berupa Panduan Praktikum berada pada grade capaian baik dan sangat baik. Hal ini berarti bahwa produk pjbl memenuhi kriteria produk yang baik.

Evaluasi proses pembelajaran dilakukan setelah nilai ujian akhir semester telah input pada system informasi akademik unima sehingga diharapkan tidak mempengaruhi independensi mahasiswa dalam menjawab kuisioner. Hasil kusioner menunjukkan respons yang sangat baik mahasiswa yang melaksanakan perkuliahan dengan metode project based learning. Hasil penelitian ini sejalan dengan beberapa laporan penelitian bahwa pembelajaran berbasis project menciptakan tantangan baru bagi mahasiswa yang mulai bosan belajar mandiri di masa pandemic covid 19 (Jariyah dan Tyastirin, 2020; Muliadi et al., 2021; Budiman, 2021). Respons baik dan sangat baik tersebut meliputi aspek dosen, metode pembelajaran, evaluasi, produk yang dihasilkan dan simpulan mahasiswa. Respons yang kurang baik hanya pada akses terhadap laboratorium. Hal ini bisa dipahami karena proses pembelajaran tahun akademik 2021/2022 masih dilakukan secara daring, dan penggunaan laboratorium terbatas serta menerapkan protocol COVID 19.

\section{Kesimpulan}

Aplikasi Project based learning pada mata kuliah Entomologi berbasis serangga didanau Tondano dapat menstimulasi peningkatkan keterampilan dasar sains dan hasil belajar mahasiswa. Project based learning sangat tepat diterapkan dalam pembelajaran mata kuliah yang membutuhkan eksperimen dimasa pandemic covid 19. Respons positif ditunjukkan mahasiswa 
terhadap metode pembelajaran problem based learning yang diaplikasikan.

\section{Ucapan terima kasih}

Disampaikan terima kasih kepada Lembaga Penelitian dan Pengabdian Masyarakat, Universitas Negeri Manado yang telah membiayai penelitian ini melalui skim penelitian terapan unggulan perguruan tinggi tahun 2021. Disampaikan terima kasih kepada mahasiswa kelas entomologi dan pranata laboratorium Biologi FMIPA Universitas Negeri Manado yang telah membantu pelaksanaan penelitian ini.

\section{Referensi}

Affandi, M., Mitsuru, T., Kamil, M., \& Suryadi, A. (2021, May). The Effect of Project Based Learning Models on Improving Student Learning Results on Entrepreneurship Education. In First Transnational Webinar on Adult and Continuing Education (TRACED 2020) (pp. 122-128). Atlantis Press.

Barry, N., Toé, P., Pare Toe, L., Lezaun, J., Drabo, M., Dabiré, R. K., \& Diabate, A. (2020). Motivations and expectations driving community participation in entomological research projects: Target Malaria as a case study in Bana, Western Burkina Faso. Malaria journal, 19, 1-10.

Budiman, J. (2021). Evaluasi Pelaksanaan Pembelajaran Daring di Indonesia Selama Masa Pandemi Covid-19. Lembaran Ilmu Kependidikan, 50(1), 45-50.

Chen, J. (2019). Designing online project-based learning Instruction for EFL learners: A WebQuest approach. MEXTESOL journal, 43(2), 1-7.

Gustia, L., \& Suhartini, S. (2021). Students' interest and cognitive learning outcomes: Biology education in high schools during COVID-19. Biosfer: Jurnal Pendidikan Biologi, 14(1), 75-85. https://doi.org/10.21009/biosferjpb.18663
John, W. T., and Thomas, W. (2000). A Review of Research on Project-Based Learning. California: TA Foundation.

Jariyah, I. A., \& Tyastirin, E. (2020). Proses dan Kendala Pembelajaran Biologi di Masa Pandemi Covid-19: Analisis Respon Mahasiswa. Jurnal Penelitian dan Pengkajian Ilmu Pendidikan: eSaintika, 4(2), 183-196.

Kusumawardini S.S. \& Tim KPT Dikti (2021). Reorientasi Kurikulum Prodi Memfasilitasi MBKM serta Team Based Project dan Case method. Paparan Seminar nasional daring, Universitas Gadjah Mada. Yogakarta, Indonesia.

Karakaya, F., Selçuk, A. R. I. K., Cimen, O., \& Yilmaz, M. (2020). Investigation of the views of biology teachers on distance education during the COVID-19 pandemic. Journal of Education in Science Environment and Health, 6(4), 246-258.

Lamarre, G. P., Juin, Y., Lapied, E., Le Gall, P., \& Nakamura, A. (2018). Using field-based entomological research to promote awareness about forest ecosystem conservation. Nature Conservation, 29, 39.

Lepiyanto, A. (2017). Analisis keterampilan proses sains pada pembelajaran berbasis praktikum. BIOEDUKASI (Jurnal Pendidikan Biologi), 5(2), 156-161.

Mardhotillah, A. F., Indriyani, L. A., Wulandari, V. A., Kuraesin, P. P. S., Al, N. L. S. A. A., Irjiananto, M. Y., ... \& Rachmawati, Y. (2020). Studi Eksplorasi Kegiatan Praktikum Sains Saat Pandemi Covid19. Indonesian Journal of Science Learning, 1(2), 67-75.

Mokosuli Y. S. (2013). Karakter Morfologi, Sumber Pangan, dan Bioaktivitas Farmakologis Racun Lebah Madu Endemik Sulawesi Apis dorsata Binghami dan Apis nigrocincta Smith (Hymenoptera: Apidae). Disertasi. Program Pascasarjana Universitas Sam Ratulangi, Manado. 
Muliadi, A., Mirawati, B., \& Jannah, H. (2021). Efektivitas Pembelajaran Daring di Masa Pandemi Covid-19: Persepsi Mahasiswa Pendidikan Biologi. JISIP (Jurnal Ilmu Sosial dan Pendidikan), 5(2).

Nawawi, Trisianawati Eka., \& Karim, A. (2021). Biology Blog: Project-Based Learning in Pandemic Periode to Encourage Students' Creativity. Thabiea: Journal of Natural Science Teaching, 4(1), 111-120

Randazzo M, Priefer R and Khamis-Dakwar R (2021) Project-Based Learning and Traditional Online Teaching of Research Methods During COVID-19: An Investigation of Research Self-Efficacy and Student Satisfaction. Front. Educ. 6:662850.

doi: 10.3389/feduc.2021.662850. Received: 01 February 2021; Accepted: 07 May 2021;

Simanjuntak, S. T., \& Wahyanti, C. T. (2021). Analisis Kinerja Dosen Melaksanakan Tri Dharma Perguruan Tinggi Pada Masa Pandemi Covid-19: Studi Kasus Di Universitas Kristen Satya Wacana. JENIUS (Jurnal Ilmiah Manajemen Sumber Daya Manusia), 5(1), 86-101.

Semuel, M. Y., Wuarah, M., \& Sumampouw, H. M. (2021). Pembelajaran Biologi Berbasis Eksperimen Menggunakan Lalat Buah Isolat Lokal: Bintang Pustaka. Bintang Pustaka Madani.

Sumampouw, H. M., Semuel, M. Y., \& Oka, D. N. (2017). Analysis of cythochrome oxidase sub unit 1 Gene (CO1) of fruit fly (Droshophila sp.) from pineapples and application in teaching DNA in Senior high school. International Journal of Advanced Education and Research, 2(2), 71-77.

Sarwi, S., Baihaqi, M. A., \& Ellianawati, E. (2021, June). Implementation of Project Based Learning Based on STEM Approach to Improve Students' Problems Solving Abilities. In Journal of Physics: Conference Series (Vol. 1918, No. 5, p. 052049). IOP Publishing.

Torrecilla, J. S., Gutiérrez-de-Rozas, B., \& Cancilla, J. C. (2021). Thinking-Based Learning at Higher Education Levels: Implementation and Outcomes within a Chemical Engineering Class. Journal of Chemical Education, 98(3), 774-781.

Tran, T. Q., Tran, P., \& Ngoc, T. (2021). Vietnamese EFL High School Students' Use of Self-Regulated Language Learning Strategies for Project-Based Learning. International Journal of Instruction, 14(1), 459-474.

Tretten, R., and Zachariou, P. (1997). Learning about Project-Based Learning: Assessment of Project-Based Learning in Tinkertech Schools, 37. San Rafael, CA: The Autodesk Foundation.

Virtue, E. E., \& Hinnant-Crawford, B. N. (2019). "We're doing things that are meaningful": Student Perspectives of Project-based Learning Across the Disciplines. Interdisciplinary Journal of Problem-Based Learning, 13(2), 9

Yustina, Syafii W and Vebrianto R. (2020). The Effects Of Blended Learning And ProjectBased Learning On Pre-Service Biology Teachers' Creative Thinking Through Online Learning In The Covid-19 Pandemic. J. Pendidikan DOI: 10.15294/jpii.v9i3.24706

Wurarah, M., \& Semuel, M.Y. (2019). Development of Audio Visual Learning Mediaof Biology On The Concept Of DNA, Based On The Results Of Molecular Identification Of Payangka Fish From Lake Tondano. European Journal of Health and Biology Education, 8(1), 1-17. https://doi.org/10.12973/ejhbe.8.1.1 